\title{
STUDI KOMPARASI EMIK DAN ETIK MASYARAKAT TERHADAP MENJAMURNYA TAYANGAN DRAMA ASING DI INDONESIA: KAJIAN ANTROPOLOGI KONTEMPORER
}

\author{
Siti Maryam \\ Universitas Muhammadiyah Jember \\ Pos-el: sitimaryam@unmuhjember.ac.id
}

\begin{abstract}
Abstrak
Bahasa merupakan suatu hal yang telah membuat manusia menjadi makhluk istimewa. Sejak lahir, setiap manusia telah dibekali dengan alat akuisisi bahasa yang sering diistilahkan dengan Language Acquisition Device (LAD). Seiring dengan berkembangnya zaman dan teknologi yang semakin maju, semakin berkembang pula dunia perfilman di setiap negara, terutama negara India, Korea, Amerika Latin, Filipina, dan Turki. Seperti yang kita lihat, belakangan ini sekitar tahun 2014 sampai sekarang, drama-drama India, Korea, Amerika Latin, Filipina, dan Turki yang sedang marak di layar kaca Indonesia. Dalam hal ini, karena semakin maraknya drama-drama luar, maka banyak sekali pengaruh yang ditimbulkan drama-drama tersebut kepada masyarakat Indonesia terutama para remaja, misalnya karena sering menonton drama Korea mereka jadi mengikuti gaya bicara, berpakaian, dan bahasanya seperti, Annyeong Haseyo (Hallo), Gamsamhamnida (Terima Kasih), Mianhae (Maaf), dan masih banyak lagi. Hal serupa juga sama dilakukan bagi masyarakat yang menyukai drama India, Amerika Latin, Filipina, dan Turki. Tidak disangka dari drama tersebutlah budaya dari negara-negara tersebut jadi semakin dikenal oleh bangsa Indonesia. Oleh karena itu, dianggap penting untuk melakukan kajian tentang persepsi masyarakat terkait menjamurnya drama asing di Indonesia sebagai bahan informasi untuk menambah wawasan masyarakat. Adapun drama yang dimaksud terwujud dalam bentuk film, sebab antara film dengan drama memiliki persamaan terutama dalam ihwal bentuk tayangan dan konten yang disajikan. Hal tersebut yang menyebabkan terjadinya berbagai persepsi di tengah masyarakat yang menikmatinya.
\end{abstract}

Kata kunci: komparasi, emik dan etik, drama asing, antropologi kontemporer

\begin{abstract}
Language is something that has made human a special being. Since birth, every human has been equipped with language acquisition tools that are often called the Language Acquisition Device (LAD). Along with the development of the era and the progress of technology, the more developed the world of cinema in every country, especially India, Korea, Latin America, Philippines, and Turkey. As we see, lately around 2014 until now, the dramas of India, Korea, Latin America, Philippines, and Turkey are often broadcasted on the Indonesian television. In this case, since the increase of the widespread of foreign dramas, many influences caused by those dramas to Indonesian, especially the teenagers. For instance because of watching Korean dramas, the youth follow the style of speech, dressing, and language like, Annyeong Haseyo (Hallo), Gamsamhamnida (Thank You), Mianhae (Sorry), and so on. The same is also true for people who love India, Latin America, Philippines, and Turkey dramas. Unexpectedly, based on those dramas, the culture of those countries become increasingly recognized by Indonesian people. Therefore, it is considered important to conduct a study on public perceptions related to the proliferation of foreign dramas in Indonesia as an information material to increase community insight. About dramas is being in the film, causes between film and dramas having the same is the structure of showing and content. That's same be the caused of perception variated in the people community.
\end{abstract}

Key words: comparation, emik and ethics, foreign drama, contemporary anthropology 


\section{PENDAHULUAN}

Bahasa adalah seperangkat kemampuan yang telah membuat manusia menjadi makhluk yang berbeda dengan yang lainnya. Sejak lahir, setiap manusia telah dibekali dengan alat akuisisi bahasa yang sering diistilahkan dengan Language Acquisition Device (LAD). Selanjutnya, manusia membangun peradaban maupun mengekspresikan hidupnya menggunakan bahasa, sehingga pada intinya manusia tidak akan pernah terlepas dari bahasa. Hal tersebut disebabkan bahwa bahasa telah menjadi alat komunikasi utama dalam kehidupan manusia. Dalam hal ini, bentuk komunikasi manusia melalui bahasa sangat beragam, yaitu secara tulis melalui kegiatan menulis dan secara lisan melalui kegiatan berbicara. Jika komunikasi dilakukan dengan menulis, maka tidak ada alat ucap yang ikut terlibat di dalamnya. Sebaliknya, jika komunikasi dilakukan melalui kegiatan berbicara, alat ucaplah yang memegang peranan penting. Bentuk komunikasi yang demikian itu bersifat produktif dan tentu menghasilkan bunyi bahasa. Berbicara mengenai bahasa dan komunikasi, maka hal tersebut tidak bisa juga dilepaskan dari konsep kebudayaan. Salah satu konsep kebudayaan yang dimaksud ialah yang tertuang dalam seni. Adapun seni yang lebih spesifik di sini yang terkait dengan dunia perfilman (drama layar kaca). Hal tersebut dikarenakan dunia perfilman, khususnya drama serial yang ditayangkan di layar kaca telah berkembang sedemikian rupa. Bahkan seni drama serial telah menjadi salah satu alat pengenalan dan penyebaran budaya oleh bangsa yang satu kepada bangsa lainnya, tidak terlepas pula kepada bangsa Indonesia. Seiring dengan berkembangnya zaman dan teknologi yang semakin maju, semakin berkembang pula dunia perfilman di setiap negara, terutama negara penghasil drama yakni India, Korea, Amerika Latin, Filipina, dan Turki. Seperti yang kita amati, belakangan ini sekitar tahun 2014 sampai sekarang, banyak drama-drama India, Korea,
Amerika Latin, Filipina, dan Turki yang sedang marak di layar kaca Indonesia. Misalnya saja drama Korea yaitu drama Full House yang dibintangi oleh Song Hye Ko dan Rain, lalu drama Secret Garden yang dibintangi oleh Hyun Bin dan Ha Ji Won, lalu drama Boys Over Flowers yang dibintangi oleh Go Hye Sun dan Lee Min Ho, dan masih banyak lagi. Sementara itu, drama India dan Turki seperti Uttaran, Mahabarata, Mahaputra, Veera, Kahlil dan Gibran, Zoya, Naagin, Gangga, Abad Kejayaan, Sehrazat, Winter Suns dan masih banyak lagi. Begitu pula dengan drama seri dari Amerika Latin yang dikenal dengan telenovela dan barubaru ini kemunculan drama seri dari Filipina turut meramaikan persaingan dalam meraih penonton Indonesia. Umumnya, penggemar drama India, Amerika Latin, dan Turki didominasi oleh ibu-ibu rumah tangga, sedangkan untuk drama Korea dan Filipina mayoritasnya adalah anak-anak muda usia remaja. Namun demikian, tidak menutup kemungkinan bila baik itu ibu-ibu maupun anak remaja juga sama-sama menyukai kelima drama tersebut. Meskipun tidak ada penelitian ke arah yang signifikan, namun hal tersebut sudah terlihat sendiri di kehidupan sehari-hari masyarakat yang hampir setiap siang sampai malam drama tersebut ditayangkan di beberapa stasiun televisi seperti Indosiar, Antv, Net TV, RCTI, Trans7, dan SCTV. Dalam hal ini, karena semakin maraknya drama-drama asing, maka banyak sekali pengaruh yang ditimbulkan drama-drama tersebut kepada masyarakat Indonesia terutama para remaja, misalnya karena sering menonton drama Korea mereka jadi mengikuti gaya bicara, berpakaian, dan bahasanya seperti, Annyeong Haseyo (Halo), Gamsamhamnida (Terima Kasih), Mianhae (Maaf), dan masih banyak lagi. Selain itu, mereka juga mencari tahu hal-hal yang dilakukan oleh bintang drama tersebut di internet atau media sosial seperti mencari tahu akun instagram, facebook, twitter, soundtrack drama, tanggal lahir, makanan favorit, maupun berita- 
berita baru mengenai bintang drama tersebut. Hal serupa juga sama dilakukan bagi masyarakat yang menyukai drama India, Amerika Latin, Filipina, dan Turki. Tidak disangka dari drama tersebutlah budaya Korea, Amerika Latin, Filipina, India maupun Turki jadi semakin dikenal oleh bangsa Indonesia. Bahkan dunia K-Pop dan lagu India sudah semakin terkenal dan telah merasuki pikiran bangsa Indonesia. Hal ini dibuktikan di laptop atau gadget mereka playlist-nya semuanya adalah lagu-lagu luar negeri dan juga video, film, dan dramadramanya lebih banyak dari luar negeri. Oleh karena itu, dianggap penting untuk melakukan kajian tentang persepsi masyarakat terkait menjamurnya drama asing di Indonesia sebagai bahan informasi untuk menambah wawasan masyarakat. Wawasan yang dimaksud berkaitan dengan komponen-komponen emik dan etik mengenai persepsi masyarakat tersebut. Adapun komponen-kompenan tersebut nantinya didasarkan pada teori antropologi.

Dalam pada itu, drama juga merupakan salah satu karya seni yang diwujudkan dalam bentuk film. Film lebih dikenal oleh masyarakat luas sebagai bagian dari seni peran yang di dalamnya sebenarnya terdapat hal atau unsur yang merupakan bagian dari suatu karya drama. Namun demikian, pada intinya yaitu drama dan atau film merupakan dua hal yang konsisten dalam persamaan struktur tayangan dan kontennya sehingga masyarakat pun sudah mulai memahami konsep drama maupun film tersebut. Adapun sebagai bagian dari karya seni, maka drama pun tidak terlepas dari konteks persepsi, baik persepsi tafsir dari masyarakat maupun persepsi tafsir dari peneliti atau pihak-pihak yang mengkajinya secara akademis. Persepsi yang lahir dari masyarakat pemilik atau penikmat drama tersebut disebut sebagai emik dan persepsi yang berasal dari pihak luar masyarakat (peneliti) merupakan suatu hal yang disebut etik. Emik dan etik memiliki konsep dan konteksnya masing-masing, namun yang terpenting ialah bahwa keduanya sangat dibutuhkan dalam pementasan hingga penelitian terkait drama. Hal tersebut karena melalui konsep emik, maka drama tersebut mendapat nilai tafsir yang luas oleh masyarakat yang memiliki atau menikmatinya. Begitu pula dengan etik dari pihak luar yang dalam hal ini peneliti, diperlukan sebagai penyeimbang atau penyelaras persepsi masyarakat dalam emik tersebut sehingga akan terwujud kombinasi yang baik dalam penafsiran suatu tayangan drama melalui dua hal tersebut.

Berdasarkan latar belakang tersebut, terdapat permasalahan yang menjadi bahan kajian penelitian ini. Adapun permasalahan yang dimaksud dalam penelitian ini yaitu bagaimanakah komparasi emik dan etik masyarakat terhadap menjamurnya tayangan drama asing di Indonesia berdasarkan teori antropologi kontemporer. Selain itu, penelitian yang baik tentunya memiliki tujuan sebagai representasi dari rumusan masalah penelitian tersebut di atas. Adapun tujuan yang ingin dicapai dalam penelitian ini yaitu mendeskripsikan komparasi emik dan etik masyarakat terhadap menjamurnya tayangan drama asing di Indonesia berdasarkan teori antropologi kontemporer. Selanjutnya, penelitian yang dilakukan diharapkan memberikan berbagai manfaat, baik secara teoretis maupun secara praktis. Adapun penelitian ini secara teoretis diharapkan akan dapat memberikan kontribusi bagi perkembangan ilmu linguistik dan antropologi. Kontribusi yang dimaksud khususnya yang berhubungan dengan kajian kebahasaan dan kebudayaan masyarakat. Penelitian ini juga memiliki manfaat praktis bagi masyarakat. Manfaat praktis yang diharapkan adalah hasil penelitian tersebut dapat dijadikan sebagai referensi agar masyarakat dapat memahami konsep emik dan etik dalam menghadapi konteks kehidupan berbahasa dan berbudayanya.

Dalam hal ini, penelitian yang dilakukan mengenai komparasi emik dan etik masyarakat terhadap menjamurnya tayangan drama asing 
di Indonesia tersebut dibatasi agar tidak terlalu meluas. Adapun batasan yang dimaksud yaitu penelitian ini mengkaji komparasi emik dan etik terkait menjamurnya tayangan drama asing di Indonesia hanya pada persepsi masyarakat yang ada di Kota Mataram, Nusa Tenggara Barat dengan ketentuan lokasi, usia responden, dan waktu penelitian disesuaikan berdasarkan kebutuhan penelitian.

\section{TEORI DAN METODE}

Dalam bab ini diuraikan mengenai beberapa hal yaitu tinjauan pustaka, konsep, landasan teori dan metode yang digunakan dalam penelitian yang dilakukan ini. Adapun beberapa hal tersebut diuraikan sebagai berikut.

\section{Tinjauan Pustaka}

Dalam hal ini, diuraikan mengenai beberapa penelitian yang dianggap relevan sebagai tinjauan pustaka dengan penelitian yang dilakukan ini. Adapun beberapa penelitian relevan tersebut diuraikan sebagai berikut.

Penelitian yang dianggap relevan dengan penelitian yang dilakukan ini pernah dilaksanakan oleh Diniarti (2015) dengan judul "Pengaruh Tayangan Drama Korea di Televisi terhadap Minat Mahasiswa Mempelajari Budaya dan Bahasa Korea". Penelitian tersebut membahas mengenai efek penayangan drama Korea di televisi Indonesia pada minat dan motivasi para mahasiswa dalam mengkaji lebih mendalam tentang aspek bahasa dan kebudayaan Korea. Hasil penelitian tersebut menggambarkan bahwa berbagai judul drama seri Korea yang tayang di televisi Indonesia telah dijadikan sebagai salah satu pedoman dan acuan dalam mempelajari bahasa dan budaya Korea tersebut oleh para mahasiswa.

Penelitian lainnya juga pernah dilakukan oleh Damayana (2013) dengan judul "Komodifikasi Trend Tayangan Drama Seri India di Televisi Indonesia". Penelitian tersebut membahas bahwa trend tayangan drama seri India di televisi Indonesia telah banyak memberikan dampak bagi perilaku kebahasaan dan budaya masyarakat. Hasil penelitian menunjukkan bahwa drama seri India menjadi salah satu hal yang terus dicontoh oleh masyarakat dalam menjalankan kehidupannya, baik dari segi bahasa maupun kebudayaannya.

Penelitian berikutnya pernah dilakukan oleh Firmansyah tahun 2012 yang berjudul “Efek Popularitas Tayangan Drama Turki di Indonesia Bagi Perkembangan Pariwisata Turki dan Indonesia pada Era Globalisasi". Penelitian tersebut mengkaji dampak sosial berupa aspek pariwisata antara Indonesia dan Turki dalam kaitannya dengan penayangan drama serial Turki di televisi Indonesia. Hasil penelitian tersebut yaitu tingkat popularitas drama serial Turki di Indonesia telah memengaruhi sebagian besar masyarakat Indonesia untuk memilih berwisata ke negara tersebut selama beberapa waktu terakhir.

Penelitian yang juga berkaitan dengan hal tersebut telah dilakukan oleh Giovanny (2011) dengan judul "Frekuensi Pesan Human Interest pada Tayangan Drama Seri Asing di Televisi Indonesia". Penelitian tersebut berupaya mengkaji tentang sejauh mana efektivitas drama seri dari mancanegara yang tayang di televisi Indonesia dalam memberikan pesan kemanusiaan bagi penontonnya. Hasil penelitian tersebut memperlihatkan bahwa drama seri asing yang tayang di Indonesia telah dapat menjadi media penyampai pesan kemanusiaan bagi masyarakat Indonesia sebagai penikmat drama seri tersebut, baik secara sosial, budaya, ekonomi dan politik.

Penelitian lain yang terkait dengan emik dan etik pun pernah dilakukan oleh Nurhasnah (2010) yang berjudul "Pendekatan Emik dan Etik dalam Streotype dan Etnosentrisme Lintas Budaya dalam Drama Seri Asing di Indonesia". Penelitian tersebut membahas tentang stereotype dan etnosentrisme yang terdapat dalam berbagai budaya yang ditampilkan pada tayangan drama seri asing di televisi Indonesia. Hasil penelitian yang menggunakan pende- 
katan emik dan etik tersebut menunjukkan bahwa masyarakat Indonesia sebagai konsumen drama seri asing yang ditayangkan di televisi Indonesia masih memiliki stereotype dan konsep etnosentrisme terhadap budaya asing yang terdapat pada masing-masing drama seri tersebut.

Berdasarkan uraian yang terkait dengan beberapa penelitian terdahulu yang telah dilakukan, maka posisi penelitian yang dilakukan ini dengan penelitian-penelitian sebelumnya didasarkan pada konteks persamaan dan perbedaan, kekuatan dan kelemahan serta kelebihan dan kekurangan. Adapun persamaan penelitian yang dilakukan ini dengan penelitianpenelitian sebelumnya terletak pada objek kajian berupa drama-drama asing yang ditayangkan di Indonesia. Namun demikian, perbedaan antara penelitian yang dilakukan ini dengan beberapa penelitian sebelumnya yakni pada tataran materi penelitian atau sasaran yang ingin dicapai, misalnya penelitian sebelumnya ada yang bertujuan mendeskripsikan komodifikasi trend drama India, mengetahui dampak drama dalam aspek pariwisata, mengetahui pesan human interest, dan menjelaskan terkait dengan stereotype dan etnosentrisme lintas budaya dalam drama, sedangkan penelitian yang dilakukan ini lebih terfokus pada kajian emik dan etik masyarakat terhadap tayangan drama asing. Selain itu, kekuatan penelitian yang dilakukan ini yaitu karena lebih fokus dalam hal teori kajian yang menggunakan teori antropologi kontemporer. Sementara itu, kelemahan yang masih ditemukan dalam beberapa penelitian sebelumnya yaitu hasil-hasil penelitian tersebut masih terlalu sederhana dan belum menyentuh secara menyeluruh aspekaspek yang terdapat dalam drama asing tersebut. Kemudian, dalam konteks kelebihan penelitian yang dilakukan ini disbanding penelitian sebelumnya yaitu penelitian yang dilakukan ini mengkaji secara lengkap lima drama asing yang tayang di Indonesia yang berasal dari lima negara yaitu, India, Korea, Turki,
Amerika Latin dan Filipina, sedangkan penelitian-penelitian sebelumnya hanya mengkaji satu drama asing dari satu negara.

\section{Konsep}

Dalam hal ini, diuraikan mengenai beberapa hal sebagai konsep dalam penelitian yang dilakukan ini. Adapun beberapa konsep yang dimaksud tersebut diuraikan sebagai berikut.

\section{Bahasa}

Definisi bahasa secara umum adalah satu sistem lambang bunyi yang bersifat arbitrer yang digunakan oleh sekelompok anggota masyarakat untuk berinteraksi dan mengidentifikasikan diri (Chaer,2009:30). Sistem lambang bunyi tersebut memiliki hakikat yaitu sebuah sistem lambang, berupa bunyi, bersifat arbitrer, produktif, dinamis, beragam, dan manusiawi (Chaer dan Agustina,2010:11). Sementara itu, menurut Wareing (2007:17) bahasa adalah sebuah sistem atau lebih tepatnya sekelompok sistem (yaitu sistem bunyi, sistem tata bahasa, sistem makna). Ullman (dalam Sumarsono, 2014:22) mendefinisikan bahasa sebagai wahana komunikasi atau sebuah kode yang masih bersifat potensial yang merupakan sistem tanda yang tersimpan dalam pusat ingatan (memory), siap untuk dituangkan (diaktualisasikan), diterjemahkan ke dalam bunyi yang bersifat fisik, dalam proses tutur. Selain itu, bahasa merupakan sesuatu yang bukan hanya mencerminkan realitas, tetapi juga dapat menciptakan realitas (Eriyanto,2012:120). Bahasa juga merupakan alat komunikasi yang digunakan manusia, baik secara lisan maupun tertulis (Muslich,2012:3).

Berdasarkan berbagai persepsi yang diuraikan tersebut di atas, dapat diberikan suatu konsep mengenai bahasa. Konsep tersebut ialah bahwa yang dimaksud dengan bahasa adalah suatu sistem yang terdiri atas bunyi hingga makna yang bersifat arbitrer dan menjadi alat komunikasi dan identifikasi diri oleh masyarakat dalam proses tuturnya yang bukan hanya mencerminkan realitas, tetapi juga dapat menciptakan realitas. 


\section{Drama}

Arti drama seri dalam ranah linguistik adalah drama yang ditampilkan berseri. Program drama di Britania Raya, atau drama televisi dan drama serial televisi di Amerika Serikat, adalah konten program televisi yang menampilkan drama fiksional namun tidak jarang diambil dari kisah nyata. Program ini berbeda dari acara olahraga, acara berita, acara realitas dan acara permainan, stand up comedy dan acara varietas. Juga, istilah ini umumnya tidak biasanya digunakan untuk komedi situasi atau opera sabun.

Program televisi yang termasuk dalam drama biasanya dikategorikan dalam miniseri, film televisi atau drama seri terbatas. Satu kategori utama dari pemrograman drama, terutama di Amerika Serikat, adalah drama kejahatan. Di Indonesia, drama seri biasanya mengangkat kisah kehidupan kaum urban, yang penuh dengan percintaan, persahabatan, dan konflik sosial. Beberapa contoh drama seri Indonesia dikategorikan sebagai sinema elektronik (sinetron), seperti Si Doel Anak Sekolahan, Tersanjung, Cinta Fitri dan Tukang Bubur Naik Haji The Series. Terdapat juga saat ini drama seri asing berasal dari India, Korea, Filipina, Turki hingga Amerika Latin.

\section{Masyarakat}

Masyarakat adalah sekelompok individu atau kelompok orang yang terdiri atas berbagai etnis dan berinteraksi dengan etnis lain, baik pada wilayah yang berbeda maupun satu wilayah tutur (lihat Ardian,2011:37). Interaksi antara satu etnis dengan etnis lainnya tidak pernah lepas dari yang namanya bahasa sebagai sarana komunikasi atau interaksi manusia. Fungsi bahasa sebagai alat dan sarana komunikasi sangat berpengaruh dalam perkembangan komunikasi yang terjadi pada masyarakat, termasuk dalam konteks kebudayaan. Dengan demikian, masyarakat tidak akan pernah jauh dari unsur bahasa dalam sistem kehidupan sehari-harinya terutama dalam hal berkomunikasi karena masyarakat merupakan masyarakat tutur.

Chaer dan Agustina (2010:36) mendefinisikan masyarakat tutur sebagai suatu kelompok orang atau suatu masyarakat yang mempunyai verbal repertoir yang relatif sama serta memiliki penilaian yang sama terhadap normanorma pemakaian bahasa yang digunakan dalam masyarakat itu. Dalam hal ini yang dimaksud dengan verbal repertoir adalah seperangkat kemampuan komunikatif yang dimiliki oleh suatu individu (personal) dan juga kelompok (sosial). Oleh sebab itu, dapat disimpulkan bahwa masyarakat yang sudah pasti memiliki bahasa sebagai alat komunikasi mereka dapat dikatakan sebagai masyarakat tutur yang telah memiliki verbal repertoir baik secara personal (individu) maupun sosial (masyarakat).

Dalam hal ini pula diperoleh suatu keunikan lain yang disebabkan oleh adanya masyarakat pada suatu wilayah di Indonesia. Keunikan tersebut berupa terdapatnya masyarakat multilingual yang tentunya juga menghasilkan apa yang dinamakan masyarakat multibudaya. Masyarakat multibudaya itu sendiri adalah masyarakat yang memiliki beragam budaya sebagai bagian dari kehidupannya dan senantiasa dilestarikan sebagai salah satu unsur penting dalam sistem kehidupan berbahasa dalam masyarakat yang beragam (lihat Ardian, 2011:41). Sementara itu, menurut Parekh (dalam Ardian, 2011:43) masyarakat multikultural adalah suatu masyarakat yang terdiri dari beberapa macam komunitas budaya dengan segala kelebihannya, dengan sedikit perbedaan konsepsi mengenai dunia, suatu sistem arti, nilai, bentuk organisasi sosial, sejarah, adat serta kebiasaan ("A Multicultural society, then is one that includes several cultural communities with their overlapping but none the less distinc conception of the world, system of meaning, values, forms of social organizations, historis, customs and practice"). 
Dengan demikian, masyarakat yang memang sejak awal merupakan masyarakat yang multietnis, maka secara tidak langsung pula akan menghasilkan masyarakat multilingual dengan keragaman bahasanya dan masyarakat multibudaya dengan keragaman budaya yang dimilikinya dan hidup secara berdampingan sebagai satu-kesatuan unsur kehidupan dalam masyarakat.

\section{Landasan Teori}

Dalam hal ini, diuraikan mengenai teori yang menjadi landasan dalam penelitian yang dilakukan ini. Adapun landasan teori yang dimaksud tersebut diuraikan sebagai berikut.

\section{Antropologi Kontemporer}

Secara harfiah, antropologi adalah ilmu (logos) tentang manusia (antropos). Definisi demikian tentu kurang jelas, karena dengan definisi seperti itu antropologi mencakup banyak disiplin ilmu seperti sosiologi, psikologi, ilmu polotik, ilmu ekonomi, ilmu sejarah, biologi manusia dan bahkan humaniora, filsafat dan sastra yang semuanya mempelajari atau berkenaan dengan manusia. Sudah tentu hal ini tidak benar, apalagi disiplin-disiplin ilmu lain tersebut justru sudah berkembang jauh lebih tua dari pada antropologi.

Oleh karena itu, pasti ada sesuatu yang khusus tentang manusia yang menjadi pusat perhatian antropologi. Bidang permasalahan yang khusus dipelajari oleh antropologi tidak jelas batasnya, karena terlalu cepatnya pemisahan ilmu-ilmu cabang antropologi yang sangat berlainan bidang permasalahan yang dipelajari. Akibatnya, tidak ada satupun definisi umum yang dapat disepakati oleh semua ilmuwan antropologi. Salah satu karakteristik yang paling banyak mendapat perhatian dalam antropologi adalah hubungan antara kebudayaan dan ciri-ciri biologis manusia. Masa ketergantungan manusia pada pengangkutan jalan kaki, ukuran otak yang besar, dan kemampuan menggunakan simbol-simbol adalah contoh beberapa ciri biologis yang memung- kinkan mereka menciptakan dan mendapatkan sesuatu yang disebut dengan istilah kultur atau kebudayaan.

\section{Hubungan Manusia dengan Kebudayaan}

Di antara manusia dan kebudayaan terjalin hubungan yang sangat erat, bahwa manusia menjadi manusia merupakan suatu wujud kebudayaan. Hampir semua tindakan manusia itu merupakan kebudayaan. Hanya tindakan yang sifatnya naluriah saja yang bukan merupakan kebudayaan, tetapi tindakan demikian persentasenya sangat kecil. Tindakan yang berupa kebudayaan tersebut dibiasakan dengan cara belajar. Terdapat beberapa proses belajar kebudayaan yaitu proses internalisasi, sosialisasi dan enkulturasi. Selanjutnya, hubungan antara manusia dengan kebudayaan juga dapat dilihat dari kedudukan manusia tersebut terhadap kebudayaan. Manusia mempunyai empat kedudukan terhadap kebudayaan yaitu, sebagai 1) penganut kebudayaan; 2) pembawa kebudayaan; 3) manipulator kebudayaan; dan 4) pencipta kebudayaan.

Pembentukan kebudayaan dikarenakan manusia dihadapkan pada persoalan yang meminta pemecahan dan penyelesaian. Dalam rangka survive maka manusia harus mampu memenuhi apa yang menjadi kebutuhannya sehingga manusia melakukan berbagai cara. Hal yang dilakukan oleh manusia inilah disebut kebudayaan. Kebudayaan yang digunakan manusia dalam menyelesaikan masalah-masalahnya bisa disebut sebagai way of life, yang digunakan individu sebagai pedoman dalam bertingkah laku.

\section{Emik dan Etik}

Emik dan Etik adalah dua macam sudut pandang dalam etnografi yang cukup mengundang perdebatan. Emik (native point of view) misalnya, mencoba menjelaskan suatu fenomena dalam masyarakat dengan sudut pandang masyarakat itu sendiri. Sebaliknya, etik merupakan penggunaan sudut pandang orang luar yang berjarak (dalam hal ini peneliti) untuk 
menjelaskan suatu fenomena dalam masyarakat. Dalam etnografi, peneliti memang diharuskan untuk terlibat dalam kehidupan masyarakat yang menjadi objeknya untuk periode yang cukup lama. Di sana dia akan mengamati apa yang terjadi, mendengar apa yang dikatakan orang-orang, mengajukan pertanyaan, mengumpulkan data apa pun yang tersedia dan menjelaskan masalah yang menjadi perhatiannya.

Berdasarkan definisi di atas, wajar bila terjadi kesulitan untuk menentukan point of view mana yang harus digunakan. Karena memang keduanya tidak dapat dipisahkan secara murni satu sama lainnya. Akan tetapi, merujuk pada Boas (Webber,2015:46), bahwa "sekiranya kita benar-benar bertujuan untuk memahami pemikiran manusia, maka seluruh analisa pengalaman mestilah diasaskan pada konsep mereka dan bukannya konsep kita." Lull (Webber, 2015:47) juga menegaskan bahwa salah satu tanggungjawab dari peneliti etnografi adalah melakukan semua risetnya dalam setting yang alamiah (natural), di mana tempat perilaku itu berlangsung. Dari berbagai pertimbangan itulah, sebagian besar antropolog sangat menyarankan peneliti untuk menggunakan pendekatan 'emik' daripada 'etik'. Artinya, peneliti tetaplah include dalam kehidupan masyarakat obyeknya, namun dia harus meminimalisasi sebanyak mungkin pandangan etiknya terhadap masyarakat tersebut.

Pendekatan emik dalam hal ini memang menawarkan sesuatu yang lebih objektif. Hal tersebut dikarenakan tingkah laku kebudayaan memang sebaiknya dikaji dan dikategorikan menurut pandangan orang yang dikaji itu sendiri, berupa definisi yang diberikan oleh masyarakat yang mengalami peristiwa itu sendiri. Bahwa pengonsepan seperti itu perlu dilakukan dan ditemukan dengan cara menganalisis proses kognitif masyarakat yang dikaji dan bukan dipaksakan secara etnosentrik, menurut pandangan peneliti. Antropolog berupaya menggabungkan faktor-faktor ke dalam analisis "holistik", termasuk biologi, ekologi, linguistik, sejarah, dan ideologi. Prespektif antropologi itu komparatif karena disiplin ini mencari informasi dan menguji eksplanasinya di kalangan semua kebudayaan prasejarah, sejarah, dan kontemporer terhadap kebudayaan-kebudayaan tersebut. Secara sangat sederhana, emik mengacu pada pandangan warga masyarakat yang dikaji, sedangkan etik mengacu pada pandangan si peneliti. Kontruksi emik adalah deskripsi dan analisis yang dilakukan dalam konteks skema dan kategori konseptual yang dianggap bermakna oleh partisipan dalam suatu kejadian atau situasi yang dideskripsikan dan dianalisis. Kontruksi etik adalah deskripsi dan analisis yang dilakukan dalam konteks skema dan kategori konseptual yang dianggap bermakna oleh komunitas penganut ilmiah. Robert Lawless membahas istilah emik dan etik dalam kerangka model folk dan model analisis. Model folk adalah representasi stereotipikal, normatif, dan tidak kritikal dari realitas yang dimiliki bersama oleh para anggota suatu kebudayaan. Kemudian model analisis adalah representasi profesional, eksplanatoris, dan komprehensif dari realitas yang diakui oleh komunitas ilmiah.

Emik dan etik tidak ada kaitannya dengan ontologi. Kejadian, situasi, hubungan dan fakta, tidak pernah terkait dengan emik maupun etik. Kejadian-kejadian dan entitas yang termasuk ke dalam dunia empiris semata-mata hanya kejadian dan entitas. Suatu deskripsi, analisis, eksplanasi, atau klaim tertentu terhadap pengetahuan adalah emik atau etik haruslah didasarkan semata-mata pada dasardasar epistemologi.

Haris (Webber,2015:88) membedakan pernyataan emik dan etik atas dasar epistemologi, yaitu "kerja emik mencapai tingkat tertinggi tatkala mengangkat informan nativ pada status penilai tertinggi bagi kecukupan deskripsi dan analisis pengamat. Pengujian kecukupan dari analisis emik adalah kemampuannya menghasilkan pernyataan-pernyataan yangt dapat 
diterima natif sebagai nyata, bermakna, atau sesuai. Kerja etik mencapai tingkat tertinggi tatkala mengangkat pengamat kepada status penilai tertinggi dari kategori-kategori dan konsep-konsep yang digunakan dalam deskripsi dan analisis". Pembedaan antara data yang diperoleh atas dasar wawancara dan pengamatan saja tidak dengan sendirinya mencukupi untuk membangun status emik atau etik dari deskripsi dan analisis. Melainkan, deskripsi dan analisis tersebut harus diukur dengan menggunakan standar-standar lain yakni penilaian dari nativ untuk emik dan evaluasi dari antropologi untuk etik. Deskripsi dan eksplanasi antropologi adalah etik apabila memenuhi halhal sebagai berikut.

1. Deskripsi harus bermakna sesuai dengan komunitas luas pengamat ilmiah.

2. Deskripsi harus divalidasi oleh pengamat secara independen

3. Deskripsi harus memenuhi persyaratan berupa aturan-aturan dalam memperoleh pengetahuan dan bukti ilmiah.

4. Deskripsi harus dapat diterapkan secara lintas budaya.

5. Kajian-kajian dalam konteks teori tahaptahap perkembangan yang mengilustrasikan bahaya yang bakalan menimpa ilmuilmu sosial yang gagal membedakan emik dan etik.

Sebagai antropolog, klaim kita untuk mementingkan eksplanasi yang sahih dan dapat dipercaya terletak pada upaya kita untuk membangun pengetahuan etik, meskipun mungkin bagi kita untuk mendeskripsikan, membahas, dan membandingkan baik ilmiah maupun tidak ilmiah, baik dalam konsep emik maupun etik, eksplanasi ilmiah haruslah eksplanasi etik. Dengan menegakkan pengetahuan etik sebagai hal yang ideal, antropolog berpendirian bahwa pengetahuan antropologi itu harus mampu mengoreksi dirinya sendiri. Antropologi adalah pengetahuan objektif mengenai kondisi manusia dibenarkan oleh upaya-upaya kita yang kumulatif dan berkesinambungan untuk menguji setiap klaim terhadap pengetahuan. Kita menganggap pengetahuan etik secara obyektif sahih, terutama karena kita memandang sebagai pengetahuan tentatif.

\section{Metode Penelitian}

Penelitian yang dilakukan ini menggunakan beberapa metode dalam kaitannya dengan pengumpulan data, penganalisisan data, dan penyajian hasil analisis data. Metode-metode yang dimaksud tersebut diuraikan sebagai berikut.

\section{Metode Pengumpulan Data}

Metode yang digunakan untuk mengumpulkan data dalam penelitian ini yaitu metode observasi dan dokumentasi. Metode observasi dilakukan dengan cara berada langsung di lokasi yang terdapat objek yang diteliti dengan teknik wawancara. Selain itu, metode dokumentasi dilakukan oleh peneliti dengan mendokumentasikan keterangan atau objek yang dijadikan bahan penelitian yang dalam hal ini berupa persepsi masyarakat terhadap menjamurnya drama asing yang tayang di Indonesia.

\section{Metode Penganalisisan Data}

Penelitian yang dilakukan ini dalam hal penganalisisan data menggunakan metode analisis deskriptif dengan pendekatan kualitatif (Silalahi,2012:110). Adapun langkah-langkah yang akan dilakukan dalam penganalisisan data sebagai berikut.

1. Data-data berupa persepsi masyarakat terkait drama asing di Indonesia yang telah dikumpulkan akan direduksi sesuai kebutuhan penelitian.

2. Data berupa persepsi masyarakat terkait drama asing di Indonesia yang telah direduksi kemudian dianalisis berdasarkan konsep emik dan etik yang disampaikan oleh responden penelitian.

3. Data berupa persepsi masyarakat terkait drama asing di Indonesia yang telah diana- 
lisis secara tuntas diuarikan dalam penyajian hasil analisis data sesuai rumusan masalah penelitian.

\section{Metode Penyajian Hasil Analisis Data}

Metode yang digunakan dalam menyajikan hasil analisis data dalam penelitian ini yakni metode informal. Metode informal digunakan dalam menguraikan hasil analisis data melalui uraian atau secara naratif (Mahsun,2011:132). Oleh sebab itu, data berupa persepsi masyarakat terhadap menjamurnya tayangan drama asing di Indonesia berdasarkan konsep emik dan etik yang telah dianalisis tersebut diuraikan menggunakan kata-kata dan kalimat secara naratif.

\section{HASIL DAN PEMBAHASAN}

Dalam bab hasil dan pembahasan ini akan diuraikan hasil penelitian berupa studi emik dan studi etik terhadap drama asing yang tayang di televisi Indonesia. Adapun studi emik dan etik tersebut akan diketahui dampaknya pada bidang sosial, budaya, dan ekonomi dalam kehidupan masyarakat lokus penelitian.

\section{Studi Emik}

Dalam hal ini akan diuraikan mengenai studi emik (persepsi masyarakat). Studi emik yang dimaksud ialah yang berkaitan dengan drama asing yang tayang di televisi Indonesia.

\section{Studi Emik terhadap Drama Korea}

Drama Korea merupakan salah satu serial drama yang tayang di televisi Indonesia. Fenomena munculnya drama Korea telah muncul beberapa waktu lalu hingga digandrungi oleh sebagian besar masyarakat, khususnya kalangan remaja saat ini. Dalam pandangan masyarakat (remaja Indonesia), drama Korea memiliki daya pikat yang luar biasa sehingga dirasa layak menjadi hiburan di waktu luang. Adapun daya pikat yang menjadi studi emik terhadap drama Korea tersebut meliputi pemeran-pemeran dalam drama Korea yang secara keseluruhan berwajah tampan dan cantik menurut para penggemarnya, alur cerita yang sistematis dan menghibur, dan penyajian pesan yang juga dianggap menimbulkan kesan tersendiri bagi penikmatnya. Oleh sebab itulah, drama Korea yang tayang dalam bentuk serial di beberapa stasiun televisi swasta nasional tetap menjadi daya tarik hiburan bagi masyarakat, khususnya kalangan remaja zaman sekarang.

Emik yang terjadi di tengah kehidupan masyarakat terkait dengan keberadaan drama Korea tersebut telah berlangsung dalam waktu lama. Hal tersebut karena semakin menjamurnya drama-drama Korea yang ditayangkan di layar televisi Indonesia. Drama-drama Korea yang dimaksud seperti Boys Before Flowers, The Heirs, Full House, Secret Garden hingga Descendants of The Sun. Berbagai drama asal Korea tersebut dapat dianggap sebagai sesuatu yang sudah menjadi konsumsi wajib bagi para penikmatnya, khususnya kalangan remaja yang selalu gandrung terhadap kemunculan juduljudul atau tokoh-tokoh baru dalam drama Korea yang ditayangkan tersebut.

\section{Studi Emik terhadap Drama Filipina}

Kemunculan drama serial asal Filipina semakin menambah deretan tayangan drama asing di televisi Indonesia. Hal tersebut tentu menimbulkan beberapa persepsi di kalangan masyarakat Indonesia, baik yang berusia remaja maupun dewasa. Persepsi-persepsi yang merupakan bagian dari studi emik tersebut muncul disebabkan oleh beberapa hal yang dianggap menjadi bagian menarik dalam sajian serial drama asal Filipina tersebut. Hal-hal menarik yang dikemukakan oleh masyarakat terkait dengan drama seri Filipina misalnya, alur ceritanya menggugah dan tidak membosankan, akting dari para pemerannya sangat menjiwai, dan suasana setting drama tersebut sangat dekat dengan suasana kehidupan masyarakat, khususnya masyarakat Indonesia. Beberapa hal tersebutlah yang menyebabkan 
tayangan drama seri asal Filipina dapat diterima oleh penikmat drama di Indonesia sehingga drama seri Filipina dapat terus tayang dan bersaing dengan drama-drama asing lainnya.

Adapun drama asal Filipina yang juga selalu digemari oleh para penikmatnya akhirakhir ini seperti Two Wives, Doble Kara, Bright Love dan beberapa drama dengan durasi tayang yang cukup intens di televisi swasta nasional. Hal tersebutlah yang menimbulkan reaksi emik di tengah masyarakat berupa pandangan bahwa drama-drama asal Filipina dianggap lebih sederhana dan terbuka dengan kehidupan sosial masyarakat menengah ke bawah sehingga dapat menggugah para penikmatnya di Indonesia, khususnya di Kota Mataram sebagai lokus penelitian.

\section{Studi Emik terhadap Drama India}

Salah satu drama seri asing yang telah menjamur penayangannya di televisi Indonesia adalah drama serial India. Drama serial India tersebut digandrungi oleh masyarakat Indonesia dalam beberapa waktu terakhir. Salah satu ciri khas dari drama seri India tersebut yaitu sealu diselingi dengan lagu, musik, bahkan beberapa tradisi budaya asal India, sehingga secara tidak langsung masyarakat Indonesia dengan sendirinya mengetahui dan mempelajari unsur-unsur kebudayaan asal negeri Bollywood tersebut. selain itu, drama seri India juga dianggap mengandung berbagai pesan moral dan sosial dalam setiap tayangannya, baik yang berbentuk kisah kolosal maupun kisah sosial dan asmara yang diperankan oleh tokoh-tokohnya. Secara emik, drama seri India tetap menjadi salah satu pilihan hiburan oleh masyarakat Indonesia, terutama kalangan dewasa (ibu rumah tangga). Drama India pun menjadi salah satu fenomena hiburan televisi yang semakin digemari oleh masyarakat.

Drama-drama seri asal India yang telah menjadi bagian dari hiburan masyarakat hingga saat ini terdapat berbagai judul, baik yang berkaitan dengan kehidupan rumah tangga, asmara, mitologi maupun fantasi. Drama yang dianggap mencerminkan kehidupan berumahtangga orang India terdapat dalam drama Ranveer dan Ishani, kemudian dalam konteks asmara yaitu Veera, Saraswati chandra, dan Gangga. Sementara untuk konteks mitologi terdapat pada drama Mahabharata, Mahadewa, dan Mahaputra. Selanjutnya, drama fantasi yang dimiliki India salah satunya adalah Naagin. Keberagamaan jenis tersebutlah yang juga menjadi daya tarik emik masyarakat terhadap tayangan drama asal India.

\section{Studi Emik terhadap Drama Turki}

Kekhasan drama serial Turki yang menampilkan sisi kehidupan masyarakat dan budaya Turki yang berlandaskan atau mengandung unsur keislaman menjadi daya tarik tersendiri bagi penikmat drama seri yang sudah tayang di beberapa stasiun televisi Indonesia. Dalam pandangan emik masyarakat, kemasan situasi dan kondisi yang ditampilkan dalam drama serial asal Turki telah dapat diterima oleh masyarakat Indonesia, baik secara budaya maupun secara agama. Hal tersebut dikarenakan dalam setiap tayangan drama Turki, masyarakat penikmatnya yang juga masih didominasi kalangan dewasa (khususnya muslim) merasa berbagai hal yang disampaikan dalam drama tersebut sangat mengena dengan situasi dan kondisi kehidupan masyarakat Indonesia. Berdasarkan hal tersebut, masyarakat pencinta drama asal Turki menganggap bahwa drama seri Turki dapat dijadikan salah satu alternatif hiburan televisi pada saat ini, sehingga drama asal Turki masih tetap bertahan untuk tayang di beberapa stasiun televisi Indonesia.

Turki sebagai salah satu negara yang sedang berkembang dalam beberapa bidang saat ini juga termasuk sebagai negara yang memproduksi, memiliki dan menyebarkan drama-drama yang didominasi oleh corak kebudayaan Turki (campuran Eropa dan 
Timur Tengah, kombinasi kehidupan Islami dan Nasrani). Hal tersebut menjadi salah satu ciri khas drama Turki yang tayang di Indonesia. Drama-drama yang dimaksud misalnya Sehrazat, Winter Sun, Elif, Abad Kejayaan dan beberapa judul lainnya. Penikmat drama Turki di Indonesia, khususnya Kota Mataram yang mayoritas muslim menjadi aspek yang memudahkan drama-drama tersebut mudah diterima dan berkembang sebagai salah satu drama popular di televisi masyarakat.

\section{Studi Emik terhadap Drama Amerika Latin}

Drama serial asal Amerika Latin, khususnya Meksiko merupakan serial drama yang telah lama dan bisa dikatakan paling dahulu tayang di televisi Indonesia sebelum kemudian muncul drama-drama asing lainnya. Hal tersebut diperkuat oleh persepsi emik masyarakat yang menyatakan bahwa drama serial asal Amerika Latin merupakan yang tertua dalam hal penayangannya di televisi Indonesia. Drama seri yang lebih dikenal dengan istilah telenovela tersebut digemari oleh masyarakat Indonesia karena unsur-unsur pembangun dramanya dianggap menarik dan menghibur. Telenovela secara keseluruhan memang mengisahkan tentang kehidupan asmara dari para tokohnya yang berusia dewasa, sehingga telenovela atau drama seri Amerika Latin tersebut pun penggemarnya didominasi oleh kalangan dewasa atau yang sudah berumahtangga. Pesan dan kesan yang ditimbulkan dan diperoleh melalui telenovela tersebut dirasakan sesuai untuk dijadikan media pembelajaran dalam kehidupan rumah tangga dan asmara, selain tentunya sebagai bagian dari hiburan masyarakat Indonesia di televisi.

Adapun beberapa judul telenovela yang telah menjadi bagian dari hiburan masyarakat selama ini yaitu Ruby, Marimar, Isabela, dan judul-judul lainnya. Telenovela-telenovela tersebut secara umum dapat diterima oleh masyarakat karena kemasan cerita yang lebih dramatis disbanding drama-drama yang berasal dari negara lain. Hal tersebut yang menjadi penyebab masyarakat selalu antusias menikmati dan memberikan interpretasi terkait drama asal Amerika Latin atau telenovela yang tayang di layar televisi tersebut.

\section{Studi Etik}

Dalam hal ini akan diuraikan mengenai studi etik (interpretasi peneliti). Studi etik yang dimaksud ialah yang berkaitan dengan drama asing yang tayang di televisi Indonesia. Studi etik ini merupakan bagian dari penyeimbang terhadap studi emik yang telah dilakukan terhadap masyarakat Kota Mataram sebagai objek dan lokus penelitian ini.

\section{Studi Etik terhadap Drama Korea}

Studi etik peneliti terkait dengan drama Korea yaitu bahwa drama Korea merupakan drama asing yang memberikan banyak dampak terhadap perilaku berbahasa maupun berbudaya para penikmatnya. Hal tersebut telah banyak terbukti terutama pada kalangan remaja yang sangat menggandrungi drama Korea, baik dari sisi cerita maupun tokoh-tokoh pemainnya. Drama-drama Korea yang dimaksud yakni Boys Before Flowers, The Heirs, Full House, Secret Garden hingga Descendants of The Sun Dengan demikian, dapat peneliti interpretasikan bahwa drama Korea sangat berdampak dalam kehidupan penggemarnya di Indonesia.

\section{Studi Etik terhadap Drama Filipina}

Studi etik peneliti terkait dengan tayangan drama Filipina di televisi Indonesia ialah bahwa kemunculan drama seri asal Filipina membawa berbagai dampak bagi masyarakat Indonesia. Dampak yang dimaksud tentunya telah tampak pada pola hidup dan sistem berbudaya pada kalangan remaja dan dewasa yang cenderung meniru suasana hidup dan budaya dalam drama tersebut. Drama-drama yang memberikan dampak yang dimaksud tersebut yakni Two Wives, Doble Kara, dan Bright Love. Hal tersebut menjadi perhatian tersendiri 
dalam perkembangan penayangan drama Filipina di televisi Indonesia.

\section{Studi Etik terhadap Drama India}

Studi etik peneliti terhadap menjamurnya drama serial asal India yaitu bahwa drama serial India telah mampu memasuki sisi-sisi kehidupan bermasyarakat di Indonesia, terutama para penikmat drama India tersebut. Hal tersebut disebabkan oleh drama seri India yang sangat banyak menampilkan sisi tradisi dan budaya India dalam setiap tayangan dramanya dan notabenenya didominasi oleh ritual-ritual keagamaan Hindustan. Hal tersebut tentu harus bisa difilterisasi oleh masyarakat penikmatnya agar tetap terjaga keutuhan kehidupannya secara tradisi budaya maupun secara religi yang mayoritas di Indonesia adalah beragama Islam. Adapun drama-drama yang dimaksud yaitu Ranveer dan Ishani, Veera, Saraswatichandra, Gangga, Mahabharata, Mahadewa, Mahaputra, dan Naagin.

\section{Studi Etik terhadap Drama Turki}

Studi etik peneliti mengenai drama serial Turki yakni bahwa serial drama asal Turki tidak hanya menyampaikan kisah-kisah khas Turki, tetapi juga menyisipkan sistem kebudayaan Turki yang harus bisa dikondisikan oleh penonton Indonesia agar tidak terkontaminasi begitu saja. Dalam hal ini, walaupun Turki dalam drama-drama serialnya menampilkan sisi keislaman juga, namun terdapat pula beberapa hal kebudayaan yang tidak selalu cocok untuk masyarakat timur seperti Indonesia yang tentu harus benar-benar bisa dipilah oleh penikmat drama Turki tersebut. Drama-drama yang dimaksud misalnya Sehrazat, Winter Sun, Elif, dan Abad Kejayaan yang telah lama tayang di televisi Indonesia.

\section{Studi Etik terhadap Drama Amerika Latin}

Studi etik peneliti terhadap tayangan drama serial asal Amerika Latin ialah bahwa drama serial Amerika Latin masih perlu dikondisikan oleh masyarakat Indonesia dalam hal menikmatinya sebagai wadah hiburan. Hal tersebut dikarenakan masih sangat banyak terdapat sisi-sisi atau hal-hal yang kurang berkenan atau tidak sesuai dengan sisi kehidupan masyarakat timur seperti di Indonesia. Seperti yang diketahui, drama asal Amerika Latin masih sangat sering menampilkan sisi 'kebaratan' mereka yang tentu harus bisa difilterisasi oleh masyarakat Indonesia ketika menikmatinya. Ruby, Marimar, dan Isabela merupakan beberapa wujud drama Amerika Latin atau telenovela yang telah lama menjadi hiburan bagi masyarakat.

\section{Dampak Drama Asing bagi Masyarakat}

Drama asing yang tayang di televisi Indonesia tentu membawa berbagai dampak dalam kehidupan masyarakat Indonesia, khususnya masyarakat Kota Mataram. Adapun dampakdampak yang dimaksud diuraikan sebagai berikut.

\section{Dampak Sosial}

Dalam hal ini, terdapat dampak sosial yang dihasilkan oleh tayangan dari berbagai drama asing di televisi bagi masyarakat Indonesia. Dampak sosial yang dimaksud yaitu masyarakat Indonesia, khususnya para peminat drama asing menjadi masyarakat yang cenderung pasif dan non-produktif. Hal tersebut disebabkan oleh terlalu seringnya mereka menghabiskan waktu untuk menonton atau menikmati hal-hal yang berkaitan dengan drama asing pilihan mereka. Dengan demikian, waktu mereka untuk menghasilkan sesuatu yang produktif menjadi sangat minim atau sedikit, termasuk dalam hal bersosialisasi dengan masyarakat lainnya.

\section{Dampak Budaya}

Dampak menjamurnya tayangan drama asing di televisi Indonesia juga terdapat dalam hal budaya. Hal tersebut tampak pada transformasi kebudayaan yang terdapat dalam masing-masing drama asing tersebut. Adapun transformasi kebudayaan yang dimaksud ialah 
bahwa masing-masing drama asing tersebut memberikan pengaruh budaya pada masyarakat Indonesia yang menyebabkan masyarakat Indonesia cenderung menggandrungi kebudayaan-kebudayaan yang ditampilkan dalam masing-masing drama serial asing tersebut tanpa melakukan filterisasi terhadapnya. Hal tersebut tentunya menjadi perhatian penting bagi berbagai pihak terkait agar tidak terjadi degradasi kebudayaan nasional akibat agresi budaya drama asing tersebut.

\section{Dampak Ekonomi}

Drama-drama asing yang tayang di televisi Indonesia juga memberikan dampak pada bidang ekonomi masyarakat Indonesia. Adapun dampak yang dihasilkan ialah bahwa tingkat kegiatan jual dan beli masyarakat menjadi lebih meningkat, khususnya pada aspekaspek yang berkaitan dengan drama-drama asing tersebut. Hal tersebut secara positif memang menjadi bagian dari sebuah perkembangan dan pertumbuhan perekonomian masyarakat, namun di sisi lain menjadi hal negatif karena masyarakat cenderung melakukan transaksi ekonomi terhadap barang-barang asing yang sesuai dengan drama-drama yang digandrungi daripada barang-barang yang berasal dari dalam negeri sendiri.

\section{Dampak Linguistik}

Bidang linguistik pun tidak terlepas dari dampak yang dihasilkan oleh tayangan dramadrama asing di televisi Indonesia. Dampak yang dimaksud lebih cenderung pada dampak yang positif bagi perkembangan linguistik masyarakat Indonesia. Adapun dampak positif yang dimaksud ialah bahwa penggunaan bahasa dalam drama-drama asing tersebut sangat memperhatikan kebakuan dan ketepatan ejaan dan pelafalan bahasa Indonesia, sehingga hal tersebut bisa menjadi bahan pembelajaran bagi masyarakat Indonesia untuk memahami penggunaan bahasa Indonesia yang baik dan benar.

\section{PENUTUP}

\section{Simpulan}

Berdasarkan uraian di atas, maka dalam hal ini dapat diberikan beberapa simpulan. Adapun simpulan yang dimaksud adalah sebagai berikut.

1. Seiring dengan berkembangnya zaman dan teknologi yang semakin maju, semakin berkembang pula dunia perfilman di setiap negara, terutama negara India, Korea, Amerika Latin, Filipina, dan Turki. Seperti yang kita lihat, belakangan ini sekitar tahun 2014 sampai sekarang, banyak drama-drama India, Korea, Amerika Latin, Filipina, dan Turki yang sedang marak di layar kaca Indonesia.

2. Konsep yang diuraikan dalam penelitian yang dilakukan ini ialah yang berkaitan dengan bahasa, drama dan masyarakat. Kemudian, teori yang melandasi penelitian yang dilakukan ini yaitu teori antropologi kontemporer dengan ruang lingkup studi emik dan etik.

3. Studi emik terhadap tayangan dramadrama asing di televisi Indonesia ialah bahwa drama-drama asing tersebut menjadi alternatif hiburan masyarakat yang sangat digandrungi, baik oleh kalangan remaja maupun dewasa.

4. Studi etik yang dilakukan peneliti terkait dengan drama-drama asing di televisi Indonesia yaitu bahwa drama-drama asing tersebut memberikan berbagai dampak yang signifikan di tengah kehidupan masyarakat.

5. Adapun dampak-dampak yang dihasilkan oleh maraknya tayangan drama-drama asing di Indonesia ialah dampak pada bidang sosial, bidang budaya, bidang ekonomi, dan bidang linguistik.

\section{Saran}

Berdasarkan hasil penelitian terkait dengan studi emik dan etik terhadap tayangan drama asing di Indonesia, maka rekomendasi selanjut- 
nya mengenai hal tersebut ialah bahwa hasil penelitian ini dapat menjadi bahan acuan atau referensi dalam pengembangan ilmu pengetahuan. Pengembangan keilmuan yang dimaksud tentunya yang terkait dengan ilmu linguistik (kebahasaan) dalam antropologi kontemporer yang mengacu pada fokus kajian studi emik dan etik masyarakat dan peneliti. Dengan demikian, hasil penelitian yang telah dilakukan tersebut dapat bermanfaat bagi masyarakat luas, terutama dalam komunikasi budayanya.

\section{DAFTAR PUSTAKA}

Ardian, Muhammad. 2011. "Studi Masyarakat Multikultural di Kota Tua Ampenan: Kampung Arab, Etnis Cina, dan Komunitas Melayu". Mataram: Universitas Mataram Press.

Chaer, Abdul. 2009. Psikolinguistik: Kajian Teoretik. Jakarta: Rineka Cipta.

Chaer, Abdul dan Leonie Agustina. 2010. Sosiolinguistik: Perkenalan Awal. Jakarta: Rineka Cipta.

Diniarti, Hidayati. 2015. "Pengaruh Tayangan Drama Korea di Televisi terhadap Minat Mahasiswa Mempelajari Budaya dan Bahasa Korea". Jakarta: UNJ Press.

Damayana, Putri. 2013. “Komodifikasi Trend Tayangan Drama Seri India di Televisi Indonesia". Surabaya: UNESA.

Eriyanto. 2012. Analisis Wacana: Pengantar Analisis Teks Media. Jogjakarta: Lkis.

Firmansyah, Yogi. 2012. “Efek Popularitas Tayangan Drama Turki di Indonesia Bagi Perkembangan Pariwisata Turki dan Indonesia pada Era Globalisasi". Surabaya: Universitas Airlangga.

Giovanny, Cahyanti. 2011. “Frekuensi Pesan Human Interest pada Tayangan Drama Seri Asing di Televisi Indonesia". Medan: Unimed Press.

Mahsun. 2011. Metode Penelitian Bahasa: Tahapan, Strategi, Metode, dan Tekniknya (edisi revisi 2011). Jakarta: Rajawali Pers.
Muslich, Masnur. 2012. Bahasa Indonesia pada Era Globalisasi. Jakarta: Bumi Aksara.

Nurhasnah. 2010. “Pendekatan Emik dan Etik dalam Streotype dan Etnosentrisme Lintas Budaya dalam Drama Seri Asing di Indonesia". Malang: Fakultas Sastra Universitas Negeri Malang.

Silalahi, Uber. 2012. Metode Penelitian Sosial. Bandung: Refika Aditama.

Sumarsono. 2014. Pengantar Semantik. Yogyakarta: Pustaka Pelajar.

Wareing, Shan dan Linda Thomas. 2007. Bahasa, Masyarakat, dan Kekuasaan. Yogyakarta: Pustaka Pelajar.

Webber, Max. 2015. Budaya Populer dan Kontemporer. Surabaya: Mediatama Pustakaraya. 